\title{
IMPACT OF PHYSIOTHERAPY ON THE CALF MUSCLE TORQUE VARIABILITY AFTER ACHILLES TENDON RUPTURE
}

\author{
Vaida Aleknavičiūtėi, 2, Rima Solianik², Dovilè Kielë2, Laimutis Škikas², \\ Nerijus Masiulis ${ }^{2}$, Albertas Skurvydas ${ }^{2}$ \\ Šiauliai State College ${ }^{1}$ \\ Lithuanian Academy of Physical Education ${ }^{2}$
}

\section{SUMMARY}

It has been established that muscle torque variability determines movement stability during the task [1]. Calf muscle weakness, ankle range of motion reduction and postural misbalance are common pathological limitations after Achilles tendon rupture (ATR). Most studies analyse rehabilitation influence for muscle strength and body balance, but there is a lack of information about calf muscle torque variability.

The aim of the study was to determine ankle plantar flexion and dorsal flexion muscle maximal voluntary contraction torque and variability Q.

Organization and methods. We measured five males, (aged $29 \pm 6$ ) after 6.5 - week surgery of ATR. Participants performed isometric ankle flexion and extension force with injured and non-injured legs. Muscles maximal voluntary contraction (MVC) torque and torque variability were measured at $-15^{\circ} ; 0^{\circ} ; 15^{\circ}$ angles. The variability of target force was $20 \%$ of MVC torque. Rehabilitation programme consisted of balance, muscle strength and stretching exercises. Calf muscle MVC torque and variability were observed before and after 8-week rehabilitation.

The results of the research. We determined that after physiotherapy the injured and the non-injured leg isometric ankle flexion and extension muscle MVC torque increased and muscle torque variability decreased.

Keywords: muscle torque variability, isometric maximal voluntary contraction torque, rehabilitation suformavimas.

\section{INTRODUCTION}

The Achilles tendon serves the basic function of connecting the soleus and gastrocnemius muscles to the calcaneus bone to allow plantar flexion about the ankle joint [2]. According to literature, Achilles tendon is one of the most commonly ruptured tendons in the human body [3]. Achilles tendon rupture influences decreased ankle range of motion, calf muscle weakness, and body balance disturbance $[4,5]$. Muscle weakness is the rationale influencing decreased free movement ability [6].

Having ruptured the Achilles tendon, mechanoreceptor activity [1] is disturbed. Movement stability and accuracy depends on the amount and quality of the proprioception information. According to literature, the muscle torque variability (movement stability) depends on the muscle torque, task complexity and somatosensory information [7]. Disrupted afferent information from joints, muscles and tendons, increases muscle torque variability [8]. It has been established that the movement during the task could be improved when it is performed with visual feedback and lasts more than $150 \mathrm{~ms}$ [5]. Information from visual feedback as well as from muscles and tendons is important to movement stability during the task [9].

According to literature, ruptured Achilles tendon stiffness and strength can be affected most within the first 18 weeks after the Achilles damage occurred. Longer period of time reduces such influence [10]. If the Achilles tendon stiffness and strength are not restored, the probability of repeated tendon rupture $[4,11]$ of the same or the other leg increases. It has been established that physiotherapy (PT) influences calf muscle torque and body balance, but there is a lack of information about PT influence on the calf muscle torque variability changes. In addition, the examination of the Achilles tendon healing possibilities could help to provide a better understanding of how PT may influence the properties of scared Achilles tendon and avoid tendon re-rupture. Therefore, the purpose of this study was to estimate the eight-week physiotherapy effect on the calf muscle maximal voluntary contraction torque and variability after Achilles tendon rupture.

\section{METHODS AND ORGANIZATION}

Research was carried following the principles of the Declaration of Helsinki. Five males (aged $29 \pm 6$ ) after Achilles tendon rupture surgery were tested. All measurements were made twice: the first -6.5 weeks after Achilles tendon surgery and the second - after 8-week physiotherapy (Figure).

All participants were tested employing "Biodex medical System PRO 3". The subjects were secured on an adjustable chair in a slightly reclined position: hip flexed at $75^{\circ}$, knee at $30^{\circ}$ angle and strapped at the chest. The foot was held in place by a heel block and was tightly attached to the plate by two straps. One strap was placed around the foot, $1-2 \mathrm{~cm}$ proximal to the metatarsophalangeal joint of the toe, and the second strap was placed around the foot, just below the ankle joint. The position of the subject was adjusted to obtain a $90^{\circ}$ angle for the ankle (neutral position $0^{\circ}$ ). To correct the effect of gravity on the measured joint movements, the passive mass of the foot was measured in the dynamometer at $15^{\circ}$ ankle angle. All subjects were tested without shoes. 


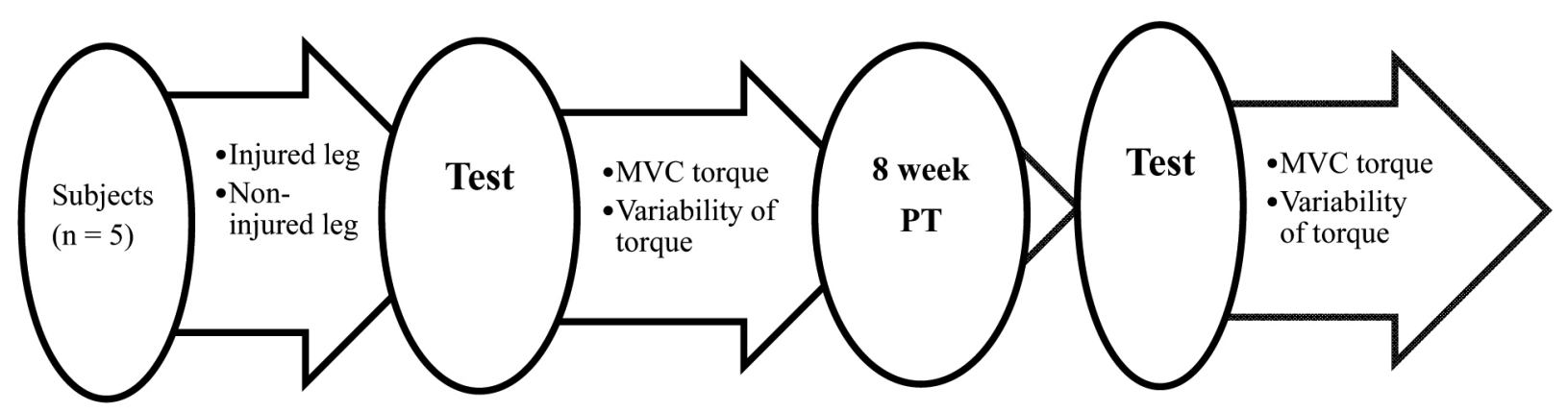

Figure. Scheme of research organization

Plantar and dorsal flexion muscles isometric maximal voluntary contraction (MVC) torque was measured in the non-injured and injured leg. The test started from the non-injured leg. Calf muscle MVC torque for each participant was tested randomity at $-15^{\circ}, 0^{\circ}, 15^{\circ}$ ankle angles. Participants at each ankle angle performed two ankle flexion and extension repetitions. The rest period between repetitions was 30 seconds, and between different ankle angles -60 seconds.

Plantar and dorsal flexion muscles isometric variability of torque (VT) was measured in the noninjured and injured legs. The test started from the noninjured leg plantar flexion, then dorsal flexion muscle VT. Calf muscle VT was tested at $-15^{\circ}, 0^{\circ}, 15^{\circ}$ ankle angles, which corresponded to ankle angles performed at MVC torque measurement. Isometric torque variability was established during the 20 second isometric contraction at the target torque equal to $20 \%$ of isometric MVC torque. The participants were asked to perform the task as accurately as possible. Participants at each ankle angle performed three ankle flexion and extension repetitions: two with visual feedback (VF) and one without visual feedback (VF). The rest period between repetitions was 30 seconds and between different ankle angles - 60 seconds.
Mathematical statistics. The research data were processed employing Microsoft Excel 2007 software for mathematical statistical analysis. The data are reported as group mean values \pm standard deviations (SD). Changes between the injury effect (the injured and noninjured leg), time impact (before and after PT), the task (with or without visual feedback) were evaluated using Student's $t$ test $(p<0.05$ level of significance).

Physiotherapy (PT) took eight weeks, three times per week; one session lasted 45 minutes. The PT program was directed toward recovery of motion, power and proprioception. All exercises were performed without pain and intensity increased over the 8-week PT program period. Each session started with gentle 10 minute warm up. In pronounces ankle joint stiffness, ankle and subtler join mobilization was performed in addition to increase range of motion. For gastrocnemius and soleus muscles, tendon complex stretching exercises were started gently and became more intensive. Eccentric strength training exercises were applied to increase plantar flexor muscles strength. Resistance exercise were started from isometric and open chain and gradually increased to isokinetic and close chain. Body balance as well as weight bearing on both legs exercises were applied for proprioception improvement.

\section{RESULTS}

Muscle maximal voluntary contraction torque measurements. Before and after PT, plantar flexion (Table 1), muscle MVC torque at $-15^{\circ}, 0^{\circ}, 15^{\circ}$ ankle angles was better $(p<0.05)$ in the non-injured compared to the injured leg. Having compared results before and after PT, MVC torque increased $(p<0.05)$ in the injured leg at $-15^{\circ}(59.27 \pm 27.05 \%)$, in the non-injured leg at $0^{\circ}$ $(15.29 \pm 10.7 \%)$ and at $15^{\circ}(21.62 \pm 16.1 \%)$ ankle angles .

Dorsal flexion (Table 2) muscle MVC torque was better $(p<0.05)$ in the non-injured compared to the injured leg at $-15^{\circ}, 0^{\circ}, 15^{\circ}$ angles before $\mathrm{PT}$, and at $0^{\circ}$ after $\mathrm{PT}$. Having compared data before and after PT, isometric MVC torque at $-15^{\circ}$ angle increased $(p<0.05)$ in the non-injured $(44.87 \pm 12.57 \%)$ and in the injured (38.63 $\pm 14.08 \%$ ) leg as well as at $0^{\circ}$ angle in the non-injured $(26.74 \pm 15.44 \%)$ and in the injured $(31.45 \pm 10.49 \%)$ leg.

Musclesisometric variability oftorque measurements. After PT, plantar flexion (Table 3) muscles VT was better $(p<0.05)$ in the injured compared to the non-injured leg at $15^{\circ}$ angle without VF. Having compared the data before and after PT, the non-injured leg VT decreased $(p<0.05)$ : at $0^{\circ}$ angle without $\operatorname{VF}(68.42 \pm 13.8 \%)$ and with VF $(59.88 \pm 28.14 \%)$, as well as at $15^{\circ}$ angle without VF $(62.87 \pm 27.24 \%)$ and with VF $(49.10 \pm 29.43 \%)$. Injured leg VT decreased $(p<0.05)$ : at $-15^{\circ}(59.20 \pm 23.13 \%), 0^{\circ}$ $(66.43 \pm 12.63 \%), 15^{\circ}(64.99 \pm 27.55 \%)$ angles without $\mathrm{VF}$, and at $15^{\circ}(66.76 \pm 22.78 \%)$ ankle angles with VF. Before PT, injured leg VT was better $(p<0.05)$ in task with VF, compared to task without VF.

Having compared the data before and after PT, dorsal flexion (Table 4) muscles VT decreased $(p<0,05)$ in the non-injured leg: at $0^{\circ}$ angle $(63.21 \pm 25.47 \%)$ without $\mathrm{VF}$ and at $15^{\circ}$ angle $(71.87 \pm 25.79 \%)$ with $\mathrm{VF}$, as well as in the injured leg decreased $(p<0.05)$ at $0^{\circ}$ angle $(59.14 \pm 12.8 \%)$ without VF. 
Table 1. MVC torque of plantar flexion muscle changes

\begin{tabular}{|c|c|c|c|}
\hline Ankle angle, degrees & Time laikotarpis & Non-injured leg, $\mathrm{N} \cdot \mathrm{m}$ & Injured leg, $\mathrm{N} \cdot \mathrm{m}$ \\
\hline \multirow{2}{*}{-15} & Before PT & $171.9 \pm 35.64$ & $180.66 \pm 61.4 *$ \\
\cline { 2 - 4 } & After PT & $222.96 \pm 33.64$ & $103.3 \pm 33.42 *$ \\
\hline \multirow{2}{*}{0} & Before PT & $143.84 \pm 18.24 \#$ & $143.89 \pm 20.17 *$ \\
\cline { 2 - 4 } & After PT & $11.43 \pm 14.41$ & $70.64 \pm 17.4 *$ \\
\hline \multirow{2}{*}{15} & Before PT & $94.56 \pm 25.26 \#$ & $89.87 \pm 19.82 *$ \\
\hline
\end{tabular}

Note. $(x \pm S)$ - average \pm standard deviation; ${ }^{*}-p<0.05$, changes between the injured and non-injured leg; $\#-p<0.05$, changes before and after physiotherapy.

Table 2. MVC torque of dorsal flexion muscle changes

\begin{tabular}{|c|c|c|c|}
\hline Ankle angle, degrees & Time & Non-injured leg, $\mathrm{N} \cdot \mathrm{m}$ & Injured leg, $\mathrm{N} \cdot \mathrm{m}$ \\
\hline \multirow{2}{*}{-15} & Before PT & $30.9 \pm 9.85 \#$ & $25.76 \pm 8.04 * \#$ \\
\cline { 2 - 4 } & After PT & $51.98 \pm 16.85$ & $39.68 \pm 11.5$ \\
\hline \multirow{2}{*}{0} & Before PT & $47.8 \pm 9.91 \#$ & $52.18 \pm 11.9 *$ \\
\cline { 2 - 4 } & After PT & $63.72 \pm 15.35 \#$ & $37.48 \pm 13.61 *$ \\
\hline \multirow{2}{*}{15} & Before PT & $44.02 \pm 17.16$ & $55.58 \pm 8.09$ \\
\hline
\end{tabular}

Note. $(x \pm S)$ - average \pm standart deviation; * $-p<0.05$, changes between the injured and non-injured leg; $\#-p<0.05$, changes before and after physiotherapy.

Table 3. Plantar flexion muscle variability of torque changes

\begin{tabular}{|c|c|c|c|c|}
\hline Ankle angle, degrees & Time & Task & Non-injured leg, \% & Injured leg, \% \\
\hline \multirow{4}{*}{-15} & \multirow{2}{*}{ Before PT } & With VF & $10.28 \pm 11.57$ & $11.39 \pm 6.98$ \\
\hline & & Without VF & $6.20 \pm 0.55$ & $6.59 \pm 2.25 \#$ \\
\hline & \multirow{2}{*}{ After PT } & With VF & $1.59 \pm 0.79$ & $3.94 \pm 4.98$ \\
\hline & & Without VF & $4.04 \pm 3.35$ & $4.64 \pm 2.52$ \\
\hline \multirow{4}{*}{0} & \multirow{2}{*}{ Before PT } & With VF & $8.48 \pm 7.42 \#$ & $5.99 \pm 2.40 \#$ \\
\hline & & Without VF & $8.25 \pm 2.95 \#$ & $9.37 \pm 3.83 \#$ \\
\hline & \multirow{2}{*}{ After PT } & With VF & $2.67 \pm 2.01$ & $1.66 \pm 0.59$ \\
\hline & & Without VF & $2.33 \pm 0.74$ & $3.26 \pm 2.09$ \\
\hline \multirow{4}{*}{15} & \multirow{2}{*}{ Before PT } & With VF & $10.22 \pm 6.71 \#$ & $5.49 \pm 2.96 \#+$ \\
\hline & & Without VF & $6.40 \pm 2.36 \#$ & $8.86 \pm 1.64 \#$ \\
\hline & \multirow{2}{*}{ After PT } & With VF & $2.45 \pm 0.60$ & $2.72 \pm 1.48$ \\
\hline & & Without VF & $2.33 \pm 2.03 *$ & $2.83 \pm 1.83$ \\
\hline
\end{tabular}

Note. $(x \pm S)$ - average \pm standard deviation; * $-p<0.05$, changes between the injured and the non-injured leg;

$\#-p<0.05$, changes before and after physiotherapy; $\dagger-p<0.05$ changes between tasks with and without visual feedback. 
Table 4. Dorsal flexion muscles variability of torque changes

\begin{tabular}{|c|c|c|c|c|}
\hline Ankle angle, degrees & Time & Task & Non-injured leg, \% & Injured leg, \% \\
\hline \multirow{4}{*}{-15} & \multirow{2}{*}{ Before PT } & With VF & $31.50 \pm 6.19$ & $30.13 \pm 5.86$ \\
\hline & & Without VF & $23.42 \pm 2.15$ & $25.06 \pm 1.61$ \\
\hline & \multirow{2}{*}{ After PT } & With VF & $5.03 \pm 2.13$ & $5.09 \pm 0.86$ \\
\hline & & Without VF t & $8.13 \pm 6.55$ & $7.83 \pm 5.89$ \\
\hline \multirow{4}{*}{0} & \multirow{2}{*}{ Before PT } & With VF & $11.75 \pm 18.51$ & $22.59 \pm 16.07$ \\
\hline & & Without VF & $10.62 \pm 18.51 \#$ & $14.85 \pm 7.93 \#$ \\
\hline & \multirow{2}{*}{ After PT } & With VF & $7.82 \pm 7.70$ & $15.01 \pm 18.68$ \\
\hline & & Without VF & $7.11 \pm 6.62$ & $4.26 \pm 3.46$ \\
\hline \multirow{4}{*}{15} & \multirow{2}{*}{ Before PT } & With VF & $28.01 \pm 8.77 \#$ & $7.66 \pm 3.32$ \\
\hline & & Without VF & $13.32 \pm 7.55$ & $6.42 \pm 3.89$ \\
\hline & \multirow{2}{*}{ After PT } & With VF & $3.82 \pm 1.38$ & $3.04 \pm 2.25$ \\
\hline & & Without VF & $7.04 \pm 7.10$ & $4.93 \pm 4.24$ \\
\hline
\end{tabular}

Note. $(x \pm S)$ - average \pm standard deviation; * $-p<0.05$, changes between the injured and the non-injured leg; $\#-p<0.05$, changes before and after physiotherapy.

\section{DISCUSSION}

We established that after 8-week physiotherapy calf muscle MVC torque and movement stability for persons with Achilles tendon rupture increased.

Calf muscles isometric maximal voluntary contraction (MVC) torque. After 8-week PT, injured and non-injured leg muscle isometric MVC torque increased. Injured leg plantar flexion muscle MVC torque increased at $-15^{\circ}$ and non-injured - at $0^{\circ}, 15^{\circ}$ ankle angles. Injured and noninjured leg dorsal flexion muscles isometric MVC torque increased at $-15^{\circ}, 0^{\circ}$ ankle angles. PT program consisted of eccentric muscles strengthening exercises. It is established that six week eccentric muscle strengthening exercises increased concentric and eccentric muscle strength [6]. Gastrocnemius and soleus muscles complex can perform $65 \%$ of the total $100 \%$ MVC force during the plantar flexion movement [3]. We suppose that noninjured and injured leg muscle isometric MVC torque increased due to muscles strengthening exercises.

Calf muscle isometric MVC torque was greater in the non-injured leg compared to the injured leg. Dorsal flexion ad plantar flexion muscle isometric MVC torque was greater in the non-injured leg compared to the injured leg at $-15^{\circ}, 0^{\circ}, 15^{\circ}$ ankles angles. It has been proved that isometric muscle torque differences between non-injured and injured leg remain one year after Achilles tendon rupture surgery [1]. T. Finni (2006) with coauthors examined non-injured and injured leg isometric MVC torque differences of nine persons after Achilles tendon rupture. Their results showed that after 8-week rehabilitation, plantar flexion muscles isometric MVC torque of the injured leg increased but still remained lower than that of the non-injured leg. Our results are similar to the ones of the investigators; we suppose that there was insufficient time to recover injured leg isometric MVC torque to pre-injured level.

Muscles isometric variability of torque (VT). It has been identified that muscle isometric VT shows movement stability during the task [13]. After 8 week PT non-injured and injured leg calf muscles isometric VT improved during the task. Movement stability depends on working muscle strength, muscle group performing the task, quality of visual feedback, task specificity [6, 12], the type and the intensity of the muscle contraction $[13,6]$ and the physical activity status of the individuals [6]. There is non-linear affiliation between isometric muscle torque and isometric muscle VT. Data showed that variability of torque increased linearly as the level of muscle torque increased up to $20-60 \%$ of MVC, but then decreased at muscle torque levels greater than $60-80 \%$ [7]. In addition, it has been reported that at lower level of muscle, variability of torque increases at an increasing rate because of synchronization of the motor unit [6]. Our results show decreased calf muscle isometric VT (movement stability during the task was improved); we suppose that it was influenced by increased non-injured and injured leg calf muscles isometric MVC torque.

Plantar flexion muscle isometric VT at $15^{\circ}$ ankle angle was greater in the non-injured leg compared to the injured leg, but there were no determined differences of dorsal flexion muscles between the non-injured and the injured leg. It is known that during the tendon injury, mechanoreceptors [13] are disrupted, and this disturbs optimal afferent impulse emanation to CNS [1]. We suppose that greater injured leg calf muscle isometric VT may be influenced by disturbed afferent impulses to CNS from the injured Achilles tendon.

It has been found that visual feedback information is important for the continued maintenance of muscle strength [1]. If the movement was performed with visual feedback and lasted longer than $150 \mathrm{~ms}$, proprioception information allowed to improve movement stability during the task [14]. Information about movement stability during the task is received from many sources: spinal cord, muscles, tendons, joints, skin, eyes [2]. Movement stability decreases when it is performed without visual feedback [13]. Our results show that visual feedback 
improved non-injured and injured leg movement stability during the task.

To sum up our research results, after eight-week PT programme, calf muscle isometric MVC increased and movement stability improved. However, calf muscle isometric MVC as well as isometric muscles VT remained greater in the non-injured leg than in the injured leg. We suppose that eight-week PT is an insufficiently long period to reduce calf muscle indicators between the noninjured and injured leg.

\title{
CONCLUSIONS
}

After eight-week physiotherapy non-injured and injured leg calf muscle isometric MVC torque increased

and isometric variability of torque decreased.

\section{REFERENCES}

1. Hong, S. L., Newell, K. M. (2008). Visual information gain and the regulation of constant force levels. Experimental Brain Research, 189 (1), 61-69.

2. Finni, T., Hodgson, J. A., Lai, A. M., Edgrteo, V. R. (2006). Muscle synergism during isomeric plantar flexion in Achilles tendon rupture patients and in normal subjects revealed by velocity-encoded cine phase-contrast MRI. Clinical Biomechanics, 21, 67-74.

3. Sosnoff, J. J., Valantine, A. D., Newell, K. M. (2006). Independence between the amount and structure of variability at low force levels. Neuroscience Letters, 16, 392 (3), 165-169.

4. Doral, M. N., Alam, M., Bozkurt, M. et al. (2010). Functional anatomy of Achilles tedon. Knee Surgery, Sport Traumatology, Arthroscopy, 40 (2), 256-264.

5. Magill, R. A. (2007). Motor Learning and Control: Concepts and Applications. McGraw-Hill International edition.

6. Salonikidis, K., Amiridis, I. G., Oxyzoglou, N. et al. (2009). Force variability during isometric wrist flexion in highly skilled and sedentary individuals. European Journal of Applied Physiology, 107 (6), 715-722.

7. Christou, E. A. Grossman, M., Carlton, L. G. (2002). Modeling variability of force during isometric contraction of the quadriceps femoris. Journal of Motor Behaviour, 34, 67-81.
8. Harrison, E. L., Duenkel, N., Dunlop, R., Russel, G. (1994). Evaluation of single-leg staning following anterior cruciate ligament surgery and rehabilitation. Physical Therapy, 74, 245-252.

9. Osu, R., Franklin, D. W., Kato, H. et al. (2002). Short- and longterm changes in joint co-contraction associated with motor learning as revealed. Journal of Neurophysiology, 88, 991-1004.

10. Schepull, T., Kvist, J., Anderson, Ch., Aspenberg, P. (2007). Mechanical properties during healing of Achilles tendon ruptures to predict final outcome: Pilot Roentgen stereophotogrammetric analysis in 10 patients. Musculoskeletal disorders, 8 (116), 472-483.

11. Torbert, J. T., Panchbhavi, V. (2009). Achilles tendon ruptures. Orthopeadia, 69 (3), 416-420.

12. Smigielski, R. (2008). Management of partial tears of the Gastrosoleus complex. Clinics in Sport Medicine, 27, 219-229.

13. Kaminski, T. W., Wabbersen, C. V., Murphy, R. M. (1998). Concentric versus enhanced eccetric hamstring strength training: Clinical implications. Journal of Athletic Training, 33 (3), 216-221.

14. Riemann, B. L. (2002). Is there is a link between chronic ankle instability and postural instability. Journal of Athletic Training, 37 (4), 386-393.

\section{ASMENỤ, PATYRUSIỤ ACHILO SAUSGYSLĖS PLYŠIMA, BLAUZDOS RAUMENŲ JËGOS MOMENTO RODIKLIŲ POKYČIAI PO KINEZITERAPIJOS}

\author{
Vaida Aleknavičiūtè ${ }^{1,2}$, Rima Solianik², Dovilè Kielè2, Laimutis Škikas², \\ Nerijus Masiulis', Albertas Skurvydas ${ }^{2}$
}

Šiauliu valstybinè kolegija

Lietuvos kūno kultūros akademija²

\section{SANTRAUKA}

Raumenų jègos momento rodiklių pokyčiai rodo užduoties metu atliekamų judesių stabilumą [1]. Literatūros šaltiniuose gausu informacijos apie reabilitacijos poveikị asmenų, patyrusių Achilo sausgyslès plyšimą, pusiausvyrai ir raumenų jègai, tačiau nepavyko rasti duomenų apie blauzdos raumenų jẻgos momento rodiklių pokyčius.

Tyrimo tikslas - įvertinti asmenų, patyrusių Achilo sausgyslès plyšimą, pėdos lenkiamųjų ir tiesiamųjų raumenų izometrinės maksimaliosios valingos jègos (MVJ) momento ir jègos momento rodiklių pokyčius po kineziterapijos.

Buvo tirti penki vyrai, kuriems taikytas chirurginis Achilo sausgyslès plyšimo gydymas. Sveikos ir pažeistos kojos raumenu izometrinės MVJ momento ir raumenų jègos momento rodiklių pokyčiai buvo testuoti tiriamajam lenkiant pėdą $-15^{\circ}, 0^{\circ}, 15^{\circ}$ kampais. Užduotos jègos momento variacijos koeficientas (VK) atitiko 20\% MVJ momento. Tiriamiesiems taikyta aštuonių savaičių trukmės kineziterapija (KT). Pratybos vykdavo kas antrą dieną po 45 minutes. KT programą sudarè čiurnos sąnario paslankumo didinimo, propriorecepcijos gerinimo, taip pat raumenų tempimo ir jẻgos lavinimo pratimai.

Po KT padidèjo $(\mathrm{p}<0,05)$ sveikos ir pažeistos kojos raumenų MVJ momento rodikliai. Pèdą lenkiant $-15^{\circ}, 0^{\circ}, 15^{\circ} \mathrm{kampais,}$ tiesiant $-0^{\circ}, 15^{\circ}$ kampais, MVJ momento rodikliai išliko mažesni $(p<0,05)$ pažeistos nei sveikos kojos. Pèdos lenkiamųjų raumenų jègos momento $V K$ sumažèjo $(p<0,05)$ sveikos kojos pėdą lenkiant $0^{\circ}, 15^{\circ}$ kampais, pažeistos kojos - lenkiant $-15^{\circ}, 0^{\circ}, 15^{\circ}$ kampais. Pèdos tiesiamųjų raumenų jėgos momento VK sumažèjo $(p<0,05)$ sveikos kojos pėdą lenkiant $0^{\circ}, 15^{\circ}$ kampais, pažeistos kojos $-15^{\circ}$ kampu. Raumenu jègos momento VK išliko didesnis $(p<0,05)$ pažeistos kojos nei sveikos. Nustatyta, kad po aštuonių savaičiu trukmès KT padidejjo sveikos ir pažeistos kojos raumenų MVJ momento rodikliai, sumažėjo sveikos ir pažeistos kojos raumenų jègos momento rodiklių pokyčiai.

Raktažodžiai: raumenų jėgos momento rodikliuc pokyčiai, izometrinès maksimaliosios valingos jẻgos momentas, reabilitacija. 